\title{
Tres espacios de la ciudadanía *
}

\author{
ÁNGEL RIVERO \\ Universidad Autónoma de Madrid
}

Resumen. En este artículo quiero mostrar que la ciudadanía, desde sus orígenes, está sujeta a la tensión entre las expectativas normativas asociadas al ciudadano y la ciudad y su realidad cotidiana, lo que la convierte, parcialmente, en un mito o en un ideal. En los Estados modernos el contenido de la ciudadanía se vuelve aún más difuso y contradictorio. Por un lado, la ciudadanía se vuelve un ideal melancólico o nostálgico; por otro, la relación del Estado y los individuos adopta la forma de un contrato bajo la lógica del interés privado. Por último, con la globalización, los límites territoriales que definen la ciudadanía se vuelven aún más difusos y el concepto se vuelve, si cabe, más abstracto. El artículo se pregunta si, bajo estas circunstancias, resulta todavía útil hablar de ciudadanía.
Abstract. In this article I would like to show that citizenship, from its inception, is under the strain of the normative expectations associated to both the concept of citizen and city (commonwealth) and its everyday reality and thus, in a sense, citizenship can be seen mainly as an ideal or a myth. In modern states the content of citizenship is even more incoherent and is almost an oxymoron. On the one hand, citizenship is basically a melancholic or nostalgic ideal; On the other hand, the link between the state and individuals adopt the form of a contract under the logic of private interest. Finally, under globalization, the territorial boundaries that define citizenship become even more fuzzy and the concept of citizenship turns to be, even more abstract. The article poses the following question: is citizenship, under present conditions, a still useful concept?

Un ciudadano es, en su acepción más simple, el miembro de una comunidad política, sujeto de derechos y obligaciones. La ciudadanía, por su parte, define la relación precisa entre el ciudadano y su comunidad política, la ciudad. Esta última, a su vez, no es cualquier agrupación humana. La ciudad es una agrupación artificial de ciudadanos para vivir juntos en mutuo beneficio. Esto es, es una agrupación cooperativa para beneficio individual y colectivo. Hay, por tanto, tres primeros espacios de la ciudadanía: el del ciudadano y sus rasgos definitorios; el de la ciudadanía o de la relación entre el ciudadano y la ciudad; y el de la ciudad o república y sus características. Estos tres espacios reúnen problemas muy diversos que interesan a la teoría política, a la filosofía política y a la ética. De hecho, Will Kymlicka y Wayne Norman han señalado que

* Una primera versión de este artículo se presentó como ponencia dentro del programa COMPOSTELA 2000; aprovecho esta ocasión para dar las gracias a los organizadores por su invitación y a Maurizio Viroli por sus comentarios. 
la importante discusión contemporánea sobre la ciudadanía queda explicada porque tiene la virtud de tematizar dos cuestiones que importan sobremanera en el pensamiento contemporáneo: la de los derechos individuales y la de las identidades colectivas, la cuestión de la sociedad justa y la de la pertenencia a los grupos particulares ${ }^{1}$. Sin embargo, estas preocupaciones no son nuevas. De hecho son muy antiguas, casi perennes en el pensamiento político. Así, Fray Alonso de Castrillo dejó escrito en su Tractado de Republica, de 1521, «cierta cosa es ser la compañía de la cibdad la más excelente de toda la compañía humana, porque en la cibdad se halla la conversación más dulce y más noble (...) Y así como no todo pueblo merece gozar del nombre de cibdad, así no todo poblador de la cibdad merece gozar del nombre de cibdadano (...), porque si al poblador le falta la mansedumbre de las costumbres para la conversación de sus iguales, si le falta prudencia para participar en la gobernación de la cibdad, no convenientemente se puede llamar cibdadano (...). Por ninguna otra cosa es averiguado quién sea el cibdadano, sino por la participación del poder para juzgar y determinar públicamente. Y así las condiciones que convienen al cibdadano [son] vivir en justo y en igual derecho con sus cibdadanos, ni hacerle muy vil ni hacerle soberbio, y entonces desear en su República aquellas pocas cosas que pacíficas son y honestas, donde a este tal le sentimos y llamar le solemos buen cibdadano. Y así ninguna cosa tanto conserva la compañía de la cibdad como la mansa y honesta conversación. Y de ninguna cosa así se engendra la buena conversación como de la humildad y de la igualdad del cibdadano» ${ }^{2}$. Aquí, en la prosa apretada de este largo párrafo, encontramos una definición temprana de cada uno de los tres espacios que acabo de apuntar. En primer lugar, no cualquier poblador de una ciudad es ciudadano. El ciudadano precisa de unas cualidades específicas que son: mansedumbre de costumbres, esto es, un carácter pacífico y abierto a la discusión y a la deliberación pública. Es decir, virtudes agonísticas y no polémicas; y prudencia y juicio político para participar en el gobierno de la república. En segundo lugar, la ciudadanía, la relación del ciudadano con la ciudad, está caracterizada por los siguientes rasgos: la participación en igualdad de los ciudadanos en el gobierno, la igualdad de derechos de todos los ciudadanos, y una cierta «condición igual» humilde y no vil ni soberbia. En tercer lugar, la ciudad no es cualquier tipo de pueblo o población: la ciudad es la compañía humana más excelente. La ciudad es una república, una agrupación política gobernada mediante la deliberación de los ciudadanos, y caracterizada por la igual participación política y disfrute de derechos definidos por la ciudadanía.

Parece que describir el significado de la ciudadanía era algo sencillo y carente de problemas cuando escribía Castrillo. Sin embargo, ahora las cosas

\footnotetext{
${ }^{1}$ Sobre esta discusión véase el artículo algo antiguo pero todavía interesante de Kymlicka y Norman «Return of the Citizen: A Survey of Recent Work on Citizenship Theory», en Beiner, Theorizing Citizenship, Albany, SUNY, 1995. pp. 24-27.

Alonso de Castrillo, Tractado de Republica, Instituto de Estudios Políticos, 1958 [1521],
} 
no parecen tan sencillas. Quizás tampoco lo eran entonces, aunque así lo transmita la prosa ingenua de Castrillo. O quizás la razón de esta dificultad contemporánea es que el concepto de ciudadanía ha cambiado mucho, se ha vuelto polisémico, ha viajado demasiado, ha abandonado las ciudades antiguas o renacentistas y se ha extendido por los Estados e incluso más lejos. En cualquier caso, definir el significado de lo que sea la ciudadanía en estos principios del siglo XXI se ha convertido en una tarea compleja.

He dicho antes que la discusión de la ciudadanía gira hoy, sobre todo, en torno a los derechos individuales e incluso de los grupos, y acerca de la cuestión de la pertenencia a los grupos y las identidades colectivas. Los ciudadanos de Castrillo eran un grupo de status dentro de las ciudades que participaban de su gobierno como iguales. Pero en Castrillo hay más ideología que descripción o, si se prefiere, más idealización que realismo. Probablemente, el texto de Castrillo puede entenderse como un panfleto lleno de autoridades clásicas utilizadas a modo de escudo frente a una posible persecución y destinado influir en el ambiente político creado por el conflicto entre las Comunidades de Castilla y el emperador Carlos, aunque esto último ahora no es lo que más nos interesa. Sus ciudadanos están demasiado empapados del mito clásico de la ciudadanía, su imagen es demasiado aristotélica. Esto es, los ciudadanos del Tractado de Republica de Castrillo son completamente abstractos, librescos. De hecho, no hay un solo ejemplo concreto de ciudad o de ciudadano en todo su libro. Michael Ignatieff ha llamado a esta literatura, antigua y moderna, dirigida a ensalzar al ciudadano como identidad esencial de los individuos «el mito de la ciudadanía». Se trata, desde luego, de un mito muy antiguo y la nueva moda republicana parece dispuesta a que se vuelva perenne ${ }^{3}$. No obstante, esta dimensión normativa de la ciudadanía parece resultar, por tanto, ineludible. Pero, ¿cómo debe ser un buen ciudadano en nuestro tiempo?

T. H. Marshall, el padre de la discusión contemporánea sobre la ciudadanía definió ésta como «un status conferido a aquellos que son miembros plenos de una comunidad. Todos los que poseen dicho status son iguales con respecto a los derechos y deberes con los que el status está dotado» ${ }^{4}$, situando el debate en términos jurídicos y no normativos ${ }^{5}$. De esta forma la ciudadanía señalaba un catálogo muy preciso de derechos y privilegios, junto a obligaciones y deberes que ostentaban grupos particulares de individuos (los ciudadanos). Sin embargo, la lógica del desarrollo de las democracias liberales ha hecho que la ciudadanía

\footnotetext{
${ }^{3}$ Michael Ignatieff, «The Myth of Citizenship», en Beiner, op. cit., «Western political imagination remains haunted by the ideal of citizenship enunciated in Aristotle's Politics», p. 53.

${ }^{4}$ T. H. Marshall, Citizenship and social class, Londres, Pluto, p. 18.

${ }^{5}$ Aunque la dimensión normativa es inescapable. Un ciudadano es, en su acepción más simple, el miembro de una comunidad política, sujeto de obligaciones y derechos, pero, como han señalado Berlin y Walzer, al enunciar la palabra ciudadano invocamos inmediatamente una ideología que inspirada en Atenas y Roma busca hacer de la ciudadanía la identidad básica de los individuos. En esta línea es fundamental el artículo de J. G. A. Pocock, «The Ideal of Citizenship Since Classical Times», en Beiner, op. cit.
} 
se haya extendido a la casi totalidad de la población adulta. Antes los ciudadanos eran los burgueses, los propietarios. Ahora, la ciudadanía se ha igualado a lo que antes se denominaba nacionalidad: ahora los ciudadanos y los nacionales son la misma $\operatorname{cosa}^{6}$. De esta forma, determinados privilegios, sobre todo el disfrute de plenos derechos políticos, se ha universalizado en gran medida en las democracias liberales. Junto a este igual disfrute de la ciudadanía, su universalización en las democracias liberales, resultado de las revoluciones políticas liberales y de la lógica de la igualdad que siempre ha animado la ciudadanía, se ha producido un proceso paralelo de ampliación de los derechos y los privilegios propios de la ciudadanía. Así la primera generación de derechos liberales de ciudadanía, civiles y políticos, se ha visto seguida por otros derechos de carácter radicalmente distinto: los derechos sociales y económicos (producto de la integración de la cuestión social en la ciudadanía liberal). Esta ampliación de los derechos propios de la ciudadanía ha alterado profundamente las bases de la ciudadanía liberal: ha desencadenado una lógica por la que el concepto de ciudadanía queda abierto de forma permanente a ulteriores «conquistas sociales»; ha desdibujado el hecho básico de que los derechos liberales son pura metafísica sin su contraparte de deberes y obligaciones y que, sin deberes y obligaciones, no se pueden proteger los derechos de ciudadanía clásicos de las primeras generación (los derechos civiles y políticos). El crecimiento desordenado de los derechos - lo que Marshall veía como el desenvolvimiento de la utopía progresista de la ciudadanía - amenaza con convertir la ciudadanía en un concepto meramente retórico para conseguir cada vez más del estado, menoscabando las responsabilidades de los ciudadanos. Pero la ciudadanía realmente existente es, sin necesidad de caer en el mito de la ciudadanía, un acuerdo de derechos y deberes entre individuos sancionado por el Estado. Si esto se pierde de vista, la metafísica de los derechos convierte a éstos en papel mojado. Esto es, el exceso de derechos podría acabar con los ciudadanos mismos, en tanto sujetos políticos responsables y activos, al convertirlos en seres pasivos dependientes del Estado. De hecho, allí donde se ha realizado el experimento de fundir el hombre con el ciudadano, creando el llamado nuevo hombre, lo que se ha producido es un ser dependiente totalmente del estado. Derechos sin obligaciones significa, por tanto, la muerte de la ciudadanía. Pero, al tiempo, la ciudadanía entendida como derechos es, también, ineludible. Nuevamente hemos de interrogarnos por los límites, ihasta dónde pueden llegar estos derechos? ¿Hay límites al crecimiento de la ciudadanía?

Por tanto, el contenido de este status que es la ciudadanía se ha vuelto complejo y su propia lógica de reconocimiento parece amenazar su existencia. Pero, además, se ciernen otras amenazas sobre la ciudadanía asociadas a ese fenómeno difuso que se llama globalización: la inmigración y su encaje en

${ }^{6}$ Por ejemplo, en el pasado los aborígenes norteamericanos eran «nacionales no ciudadanos» o, en el presente, se puede ser «súbdito británico» sin que esto implique ser «ciudadano del Reino Unido» (este último ejemplo es de Pocock). 
la ciudadanía; el reconocimiento de la diferencia cultural y la manera en que éste afecta al valor de la igualdad asociado a la ciudadanía; el resurgir de las identidades asociadas a las nacionalidades subestatales y el posible conflicto con la ciudadanía como identidad; las nuevas formas de ciudadanía transnacionales, como la ciudadanía europea; y, por último, el fenómeno del cosmopolitismo, el ciudadano cuya lealtad primera es la civitas maxima, y la manera en que ésta puede entrar en conflicto con la ciudadanía como status jurídico.

En este artículo quiero mostrar que aquello que entendemos por ciudadanía ahora es un conglomerado compuestos por distintos espacios, niveles, expectativas o dimensiones, muchas veces contradictorios, que han ido llenando de significados diversos y hasta opuestos dicho concepto. Esto hace que la discusión de la ciudadanía esté sujeta a tensiones conceptuales irresolubles. En primer lugar, acerca de aquello que sea, como decía Castrillo, un buen ciudadano. Por ejemplo, Ignatieff imagina al ciudadano mala persona, al ciudadano cuya lealtad hacia la comunidad política le hace denunciar a sus vecinos. Ésta sería la versión jacobina del ciudadano republicano (tristemente existente en distintos estados contemporáneos, por ejemplo, en la República Democrática Alemana había un espía por cada doscientas personas). O, por poner otro ejemplo, el ciudadano cuya lealtad cívica, se define en términos étnicos: el nacionalista. Este ciudadano tratará de forma diferenciada a los miembros de su comunidad y a aquellos que percibe como extraños socavando el principio de igualdad política y de reconocimiento en que se funda la ciudadanía. Otro modelo de ciudadano, reivindicado por Pocock, es el «individualista posesivo», aquel que espera de la ciudadanía la seguridad jurídica para realizar su vida privada. Aquí vida privada significa, como apuntó Hannah Arendt, vida falta de esa dimensión pública o colectiva que es tan esencial para los dos tipos anteriores de «buen ciudadano». Para Pocock, como para Constant y tantos otros, estar privado de dicha carga es un regalo. Para Arendt, sin embargo, es una pérdida. Por tanto, no sabemos qué sea eso del buen ciudadano porque, entre otras cosas, no sabemos cómo definir la comunidad política a la que pertenecemos ${ }^{7}$. $\mathrm{O}$, quizás, porque nuestras lealtades e identidades plurales nos hacen miembros de numerosas comunidades que, a veces pueden llegar a estar enfrentadas. Por tanto, aquello que sea nuestra ciudad, la dimensión territorial de la ciudadanía se ha vuelto algo tan complejo que hace prácticamente imposible saber qué cosa pueda ser un buen ciudadano, ibuen ciudadano de qué ciudad? En lo que sigue analizaré los problemas y tensiones asociados a la ciudadanía utilizando analíticamente esta pluralización de las repúblicas o ciudades a las que pertenece el ciudadano. La idea que subyace al artículo es que a pesar de la heterogeneidad de la ciudadanía hace falta conservar un mínimo de ciudadanía (entendida como derechos individuales y obligaciones hacia la comu-

\footnotetext{
${ }^{7}$ Obviamente, el nacionalista sí afirma una única lealtad política hacia una única comunidad. De igual manera el «republicano realmente existente» afirma la lealtad prioritaria a un estado concreto.
} 
nidad política junto a un mínimo de participación política convencional) para que los ciudadanos, al exigir responsabilidades a los poderes públicos, mantengan las condiciones de la libertad. Los tres espacios de la ciudadanía de los que me ocuparé serán, por tanto, los siguientes:

a) Los ciudadanos de las ciudades. Éstos conforman lo que denomino ciudadanía antigua o republicana porque remiten al espacio original de la ciudadanía, un espacio pequeño y caracterizado por las relaciones cara a cara y directas. Un espacio en el que la capacidad de diálogo y el juicio político eran los rasgos esenciales del ciudadano. Los rasgos esenciales de la ciudadanía eran el privilegio y la participación política. La ciudadanía todavía entraña privilegios frente a quienes no la poseen (aunque ahora coincide con la gran mayoría de habitantes de una comunidad política, en las democracias liberales). La ciudad era una «república» en el sentido definido por Viroli y Skinner ${ }^{8}$. La participación política de los ciudadanos era lo que hacía libres a las ciudades; la participación política de los ciudadanos ahora, obviamente menos intensa, es la garantía de la libertad de sus habitantes. Por tanto, la ciudadanía contemporánea todavía entraña estas dos dimensiones de privilegio y participación política.

b) Los ciudadanos de los Estados. Éstos refieren al tipo de ciudadanos que aparecen con la introducción del liberalismo y de la democracia en los modernos Estados nación. Esto es, con la conversión de los súbditos en ciudadanos. El ciudadano se define aquí, sobre todo, como un individuo que tiene garantizada su seguridad privada por medio de derechos. La ciudadanía consiste de este modo en protección de derechos individuales y, más tarde, en la plena extensión de los derechos civiles y políticas a todos los nacionales. El concepto esencial de este tipo de ciudadanía es el de derechos frente al propio estado. Lo que me importa señalar en este texto es que estos derechos no son desligables de las obligaciones por ellos implicados. Si se hace esto, la ciudadanía liberal declina y es sustituida por lo que se podría denominar ciudadanía social: derechos sin obligaciones. Esto significaría la desaparición completa del componente político de la ciudadanía. La ciudadanía liberal, la ciudadanía que nosotros conocemos, y que quiero examinar en este artículo, entiende la sociedad como una empresa benéfica, para el beneficio mutuo, y esto implica cooperación en el mantenimiento de las instituciones que salvaguardan los derechos. Por tanto, la ciudadanía contemporánea entraña de forma sobresaliente derechos, pero no puede olvidarse que esos derechos tienen costes (en ocasiones elevados), esto es, obligaciones y deberes (por ejemplo, el mantenimiento de las instituciones destinadas a proteger los derechos). Por

\footnotetext{
${ }^{8}$ Maurizio Viroli, «El significado de la libertad», Revista de libros, núm. 52, 2001. Pero sobre todo Quentin Skinner: «Free states, like free persons, are thus defined by their capacity for self government. A free state is a community in which the actions of the body politic are determined by the will of the members as a whole», Liberty before Liberalism, Cambridge, CUP, 1998, p. 26.
} 
último, la ciudad, la comunidad política asociada a esta forma de ciudadanía, es más abstracta, más contingente y más impersonal: es el mundo de los Estados.

c) Los ciudadanos del mundo. La ciudadanía cosmopolita era un viejo ideal estoico que servía para relativizar y denunciar las leyes injustas de la propia ciudad. El cosmopolitismo también, por ejemplo en el Kant de $L a$ paz perpetua o en los escritos sobre la guerra de Rousseau, perseguía arbitrar un orden internacional en el que la guerra quedará proscrita y en el que los hombres fueran respetados fuera de sus fronteras nacionales. La globalización ha añadido algunos significados nuevos a la ciudadanía cosmopolita. Los problemas transnacionales (desde el medio ambiente a los derechos humanos) hacen que todos los habitantes del globo estén afectados (en distinta medida) por problemas que desbordan las fronteras nacionales. Esto hace que, por primera vez, la ciudadanía cosmopolita deje de ser un ideal moral y comience a tener algo de sustancia política. Así, los problemas transnacionales demandan algún tipo de organización, más allá de los Estados, que sea responsable en términos políticos y a la que pueda dirigirse esa incipiente sociedad civil internacional que forman multitud de asociaciones como Greenpeace o Amnistía Internacional. Todo esto permanece aún en el terreno de la nebulosa teórica pero es claro que los Estados ya no pueden responder de gran cantidad de problemas que les desbordan. Por otra parte, y esto me interesa más aquí, la globalización ha puesto de relieve la debilidad de los fundamentos de la ciudadanía social y ha propiciado una recuperación de la ciudadanía liberal (al menos así contemplo la tercera vía puesta en marcha por Tony Blair). Por tanto, la ciudadanía contemporánea es todavía la ciudadanía de los Estados, pero esta ciudadanía de los Estados no puede ser ajena al hecho de que declina el orden internacional de Westfalia y que sin una reorganización del orden global, la ciudadanía de los Estados puede volverse un concepto vacío.

En suma, la ciudadanía entraña varios significados diversos y en tensión. El ciudadano unas veces ha de ser virtuoso afirmando su dimensión pública y otras haciendo de su privacidad su espacio esencial. La ciudadanía se define unas ocasiones en términos de deberes públicos y privilegios, y otras veces como derechos e igualdad. Por último, la lealtad política del ciudadano puede tener una dimensión local, particularista, política o étnica, estatal o abstracta e incluso universal. Todos estos ingredientes dispersos forman parte de aquello que sea la ciudadanía y no me cabe duda que, en una combinación adecuada a cada caso, son necesarios para que la ciudadanía siga cumpliendo una función esencial. Ésta ha sido y es, en cada uno de los espacios que estoy tratando, la de servir como mecanismo de protección de las libertades de los individuos. Lo importante, por tanto, será saber en qué medida y cómo pueden combinarse cada uno de estos espacios de la ciudadanía. 


\section{Los ciudadanos de las ciudades}

Ya se ha dicho que el concepto de ciudadanía tiene un origen antiguo. En la Grecia clásica, centralmente en la Atenas del siglo v a.C., los ciudadanos eran los protagonistas de la vida social y política. Por supuesto, no eran ciudadanos todos los habitantes de las ciudades, sino aquellos que disfrutaban de un cierto status. La ciudadanía, entonces, entrañaba una situación de privilegio; la conformaban aquellos que tenían una posición superior que les hacía merecedores de participar en el gobierno de las ciudades. Pero el privilegio refiere, sobre todo, a aquello que tenían frente a los excluidos. La ciudadanía de una minoría significaba la exclusión de la mayoría. Esto, por ejemplo, resulta revelador respecto a cómo son percibidos los inmigrantes hoy en las democracias occidentales. Hansen, citando a Aristóteles (libros tercero y sexto de La política) nos dice que las democracias radicales, en general, amplían al principio el número de ciudadanos incluyendo a esclavos o metecos hasta que se aseguran la mayoría en la asamblea y a partir de ese momento «se vuelven extremadamente mezquinos respecto a conceder la ciudadanía a los extranjeros, e incluso endurecen los criterios de forma que nadie más que los absolutamente necesarios comparta los beneficios» y concluye Hansen: «en consecuencia, las democracias están menos dispuestas que las oligarquías o las tiranías a ofrecer la ciudadanía a los extranjeros» ${ }^{9}$. Pero, icuáles eran estos beneficios de la ciudadanía? El primero es el rasgo esencial de la ciudadanía antigua, participación política: «gobernar y ser gobernado», como señaló Aristóteles. Los derechos políticos constituían el núcleo de la ciudadanía. Éstos incluían el participar en la asamblea, el derecho a ser magistrado, legislador o jurado. Pero no había una dimensión únicamente política de la ciudadanía, el privilegio de la ciudadanía también tenía una dimensión social. Los ciudadanos tenían derecho a poseer tierras y casas; tenían derecho a participar de las riquezas mineras de Atenas (cuyo disfrute, por ejemplo, de los beneficios de las minas de plata de Laureion, era un privilegio colectivo de los ciudadanos); también recibían dinero por el ejercicio de sus derechos políticos y por participar en los desfiles militares; tenían derecho a una cierta seguridad social cuando ya no podían valerse por sí mismos; los días festivos, sin actividad política remunerada, por último, tenían derecho a un subsidio para ir al teatro, primero para tragedias y comedias y más tarde para todo tipo de festivales ${ }^{10}$. La ciudadanía es, por tanto, posición y privilegio.

Los ciudadanos son los que están dentro del gobierno, son los que concurren en la toma de decisiones; los que están fuera, excluidos, son los no ciudadanos.

\footnotetext{
${ }^{9}$ Mogens Herman Hansen, The Athenian Democracy in the Age of Demosthenes, UOP, Norman, 1999, p. 95.

${ }^{10}$ Sobre los rasgos de la ciudadanía ateniense también es particularmente interesante el libro de R. K. Sinclair, Democracia y participación en Atenas, Madrid, Alianza, 1999. Por ejemplo, aquí se nos refiere que en su aspecto externo un ciudadano no se distinguía de un esclavo o
} 
Y estos dos sentidos, participación y privilegio, siguen formando parte de nuestra concepción contemporánea de la ciudadanía. Son ciudadanos hoy quienes tienen derechos a determinadas cosas por el hecho de pertenecer a una comunidad exclusiva, esto es, no abierta a todos. Cuando se define las condiciones de acceso a la ciudadanía, necesariamente, se están haciendo explícitas las condiciones de exclusión de otros. La ciudadanía antigua era muy participativa (el llamado ciudadano total) y muy exclusiva (menores, mujeres, metecos y esclavos quedaban fuera, esto es, la inmensa mayoría de la población). Hoy, en las democracias liberales, la participación política es mucho menos intensa (la libertad de los modernos es, sobre todo, el goce de la privacidad) pero mucho más inclusiva (ahora la inmensa mayoría de los adultos son ciudadanos), pero estos dos ingredientes característicos de la ciudadanía antigua - participación y privilegio - se mantienen. Por lo tanto, la ciudadanía antigua, de alguna manera, sigue formando parte de nuestro concepto contemporáneo de ciudadanía.

La idea del gobierno de los ciudadanos desapareció con el ocaso del mundo clásico para volver a aparecer al final de la Edad Media y, sobre todo, en el Renacimiento, característicamente en las ciudades-repúblicas italianas. En las ciudades de Castilla la Vieja hay un último destello de estas repúblicas de ciudadanos en la guerra de las comunidades (1519-1521) y nuestro Castrillo participa de lleno en la elaboración ideológica de sus fundamentos. Así, la revuelta de los comuneros sería vista como la afirmación del vivere libero contra el propósito centralizador del emperador Carlos V. Los comuneros afirmaron los derechos y libertades de las ciudades enfatizando la idea de independencia. Esto significaba, sobre todo, el mantenimiento de un orden poliárquico en el que la soberanía de las ciudades se protegía frente al cada vez más poderoso poder de los estados. Ésta es, también, la muy sugestiva interpretación que realiza José Antonio Maravall en su libro Las comunidades de Castilla. Para algunos, se trató de una revolución democrática, para otros, de la última resistencia feudal contra la modernidad política. Entre los adversarios de la libertad de las ciudades estaba Thomas Hobbes, del que hablaremos más adelante, o Voltaire, que celebró la abolición de los fueros catalanes por Felipe V como un avance hacia la libertad. Para ambos la libertad de las ciudades significaba la esclavitud de los individuos. Esto lo veremos en el capítulo dedicado a los ciudadanos de los Estados. Para otros, el naufragio de la libertad en sentido republicano, la libertad de participar plenamente, señala la pérdida de la libertad más valiosa. De hecho, Quentin Skinner en su libro Liberty before Liberalism busca hoy día rescatar esta dimensión olvidada de la libertad. Para Skinner la libertad de sus autores neo-romanos o republicanos combinaba de forma no antagónica la libertad positiva y la libertad negativa, esto es, el autogobierno y la libertad privada. De esta forma, la libertad individual como esfera libre

de un meteco, ni en su vestido, ni en sus costumbres ni en su trabajo. Es más, «el esclavo ni siquiera se apartaría a un lado para ceder el paso en una calle a un ciudadano», p. 60. 
de intervención externa sólo puede florecer en una república libre. Para Skinner, el haber separado y hasta opuesto estas dos dimensiones es uno de los rasgos más notables, y rechazables, del pensamiento político moderno y tiene un culpable: «La incapacidad de Hobbes (o quizás su rechazo) para percibir conexión alguna entre la libertad privada y la pública ha sido muy influyente» ${ }^{11}$. En la tradición republicana, a diferencia del liberalismo, la libertad no está asociada a un estado de naturaleza donde los hombres la disfrutan, aislados, en su forma más perfecta: «el verdadero sujeto o portador de la soberanía [dicen los republicanos] no es ni la persona natural del monarca ni ningún cuerpo natural de personas, sino que lo es la persona artificial del Estado». Por tanto, los republicanos, «no empiezan por la libertad de los individuos, sino más bien por lo que Milton denominó la "libertad común" o "gobierno libre", lo que Harrington denominó "la libertad de la república" y lo que, con posterioridad, Sidney llamó "las libertades de las naciones"» ${ }^{12}$. Idéntica defensa de la ciudadanía, argumentada en un estilo distinto y también muy sugerente, puede verse en el libro de Maurizio Viroli Por amor a la patria ${ }^{13}$. Allí patria es una comunidad política particular, caracterizada por la no dependencia y el autogobierno común de los ciudadanos. No es una comunidad adscriptiva, como una nación, sino una comunidad creada por los ciudadanos que la componen. Y no es una comunidad abstracta, aunque sí es artificial, sino una comunidad particular hacia la que los ciudadanos establecen lazos de identidad y simpatía.

Por tanto, la ciudadanía de la que estamos hablando tiene poco que ver con el liberalismo, que es el ingrediente fundamental de la ciudadanía contemporánea, de los Estados, pero, de alguna manera, aún permanece como parte de lo que nosotros asociamos a la dimensión pública de la ciudadanía. Es decir, esta ciudadanía tiene una dimensión normativa referida a la relación entre el ciudadano y el gobierno, muy importante, que hay que señalar y que también forma parte de nuestro concepto contemporáneo de la misma como pone de relieve la reivindicación contemporánea del republicanismo.

A este concepto de ciudadano le corresponden unas virtudes públicas fundamentales para la vida y la libertad de la ciudad. Los ciudadanos han de ser virtuosos o por lo menos se presupone que han de serlo; y las virtudes, las obligaciones de los ciudadanos convertidas mediante su ejercicio cotidiano en hábito, constituyen los cimientos firmes en los que se asienta la libertad de la ciudad. Lo primero que resulta chocante de esta concepción del ciudadano virtuoso, desde nuestra perspectiva contemporánea, es su masculinidad, por decirlo de la manera más suave posible: la ciudadanía ha sido hasta hace muy poco algo exclusivo de hombres (la primera democracia que instituyó el sufragio universal fue Nueva Zelanda a finales del siglo XIX). Ya he mencionado que

${ }^{11}$ Quentin Skinner, Liberty before Liberalism, Cambridge, CUP, 1998, p. 77.

${ }^{12}$ Ibid, pp. 3 y 23 respectivamente.

${ }^{13}$ Maurizio Viroli, Por amor a la patria, Madrid, Acento Editorial, 1997. 
la ciudadanía es esencialmente exclusiva pero la determinación genérica de la exclusividad es fundamental, mucho más que la determinación étnica, en la ciudadanía antigua, de las ciudades. Esto queda especialmente a la vista al atender la idea del ciudadano virtuoso. Las virtudes son aquello que es propio de los hombres y lo propio de los hombres es defender su ciudad, no quedarse en casa (entonces el ámbito propio de las mujeres). Ciudadanos virtuosos son aquellos que hacen cosas propias de hombres, sobre todo guerrear y defender armados sus ciudades. ¿Qué es lo que ocurre cuando los hombres hacen lo que deben como ciudadanos (la guerra para la defensa o gloria de la ciudad)? Ocurre que han de pagarse sus servicios a la ciudad. Entonces se establece una lógica, una relación, entre el ciudadano y su ciudad. El ciudadano otorga sus fuerzas e incluso su vida, si es necesario, a favor de la ciudad; la ciudad le otorga a cambio libertades y privilegios ${ }^{14}$. Ésa es la relación que define en la ciudadanía antigua la relación entre ciudad y ciudadano. De hecho, la exclusiva democracia ateniense sólo abrió de forma significativa el acceso a la ciudadanía para los extranjeros en aquellos momentos puntuales en los que necesitó aumentar sus tropas. Todavía hoy, al menos como ideal, este ciudadano virtuoso, el ciudadano republicano, aún existe ${ }^{15}$. Esta imagen del patriotismo es muy prominente, paradigmáticamente en Francia, pero también en EEUU. De hecho, entre los enemigos del nuevo republicanismo se denomina a Francia «el republicanismo realmente existente» con ánimo, justificado o no, de relativizar o incluso negar tajantemente las presuntas ventajas del ideal republicano. Y lo que se reprocha a Francia es la virilidad del ideal republicano, su homogeneidad intransigente a la hora de configurar la identidad política de los ciudadanos, y su escaso aprecio por la dimensión pública de las identidades privadas.

${ }^{14}$ Luis G. de Valdeavellano describe la aparición de los ciudadanos en la España medieval de la siguiente manera: «Con el avance de la Reconquista en los siglos XI y XII, el desarrollo de las ciudades, la formación de la nueva clase social de los burgueses o ciudadanos y la constitución de las localidades en Concejos o Municipios, los "fueros" o estatutos locales reconocieron y regularon las exenciones y los privilegios que se atribuían a los vecinos que poseían caballos y armas para combatir y que constituyeron en las "extremaduras" o zonas fronterizas milicias locales o concejiles de caballeros, muy activas y eficaces en las campañas militares contra la España islámica. En el siglo XII, estos caballeros de las villas y ciudades eran llamados caballeros pardos, probablemente por el color del traje que vestían; en el siglo XIII se generalizó llamarles caballeros ciudadanos $\mathrm{y}$, en el xv, el Arcipreste de Talavera los llama caballeros burgueses», Curso de historia de las instituciones españolas, Madrid, Alianza, 1998, pp. 326-327.

${ }^{15}$ Así, por ejemplo, Agnes Heller, en «Ética ciudadana y virtudes públicas», afirma: «Si estamos de acuerdo en que la "cosa común", la re publica, ha de estar constituida por instituciones, leyes y acuerdos sociales que están formados por los valores universales de la libertad y de la vida, por el valor condicional de la igualdad y por el valor procesal de la racionalidad comunicativa, entonces tenemos que practicar las virtudes cívicas relacionadas con tales valores. Tenemos que desarrollar en nosotros mismos las virtudes cívicas de la tolerancia radical, la valentía cívica, la solidaridad, la justicia y las virtudes intelectuales de la frónesis y la racionalidad discursiva. La práctica de tales virtudes hace que la "ciudad" sea lo que debe ser: la suma total de todos sus ciudadanos (...) Las virtudes cívicas contribuyen al bienestar de todos», en Heller y Fehér, Políticas de la postmodernidad, Barcelona, Península, 1989, p. 231. 
En suma, en la ciudadanía antigua, republicana, los hombres son formados como ciudadanos en las virtudes públicas y esto significa, sobre todo, anteponer lo público a lo privado (lo que presupone una idea de bien común de difícil percepción en una sociedad pluralista). Lo que define la virtud del ciudadano es comportarse como hombre, defender su república y también contribuir a su sostenimiento. Esto último incluye el pagar impuestos, un ingrediente muy importante de la ciudadanía republicana que no se debe olvidar. Aquí el pago de tributos contribuye al engrandecimiento y sostenimiento de la ciudad. No menos importante es participar en la defensa militar. O, más aún, en la gloria y engrandecimiento militar de la república. Ésta es la razón de que los ejércitos de conscripción, tan queridos a Maquiavelo, sean fundamentales en el republicanismo, porque ejemplifican, mejor que ninguna otra cosa, el amor a la patria. Esto es, la virtud de anteponer la defensa de lo público por encima de la propia vida. Por el contrario, tal como veremos en el siguiente epígrafe, en la lógica liberal de la ciudadanía el pago de tributos ocupa un lugar ambiguo y está, si acaso, directamente vinculado al sostenimiento de las instituciones que garantizan la protección de derechos individuales. La defensa de la ciudad, el tipo de ejército, es una cuestión meramente técnica, de eficacia y no de identidad.

\section{Los ciudadanos de los Estados}

El tipo ideal de ciudadano de las ciudades, lo hemos visto, se originó en la Atenas clásica, pero aún es visible en los modelos republicanos contemporáneos. Sin embargo, el modelo republicano de ciudadanía, a pesar de que de alguna manera convive todavía con el liberal, está muy lejos de éste. De hecho, son prácticamente opuestos en sus principios y en su concepción. En los Estados Unidos de la independencia, hubo una pugna teórica entre defensores de la ciudadanía liberal, federalistas, y defensores de un concepto republicano de ciudadanía, antifederalistas. De los primeros son ejemplo Madison, Jay y Hamilton, y de los últimos Jefferson y Payne. Los primeros defendían una comunidad política organizada sobre la protección de los derechos de los ciudadanos mediante la fragmentación del poder político. Los segundos defendían una república de ciudadanos activos, virtuosos (en Jefferson, la dimensión antigua de la ciudadanía está aún más marcada, el buen ciudadano había de ser propietario de tierras). La disputa constitucional se saldó a favor de los primeros y los ciudadanos quedaron definidos, básicamente, por su dimensión privada: el ciudadano como propietario (de su vida, de sus bienes y de sus libertades).

Si la dimensión pública es el núcleo de la ciudadanía antigua, el núcleo de la ciudadanía moderna o liberal es la dimensión privada. Si la ciudadanía antigua se orienta a la acción colectiva, expresiva, de los ciudadanos en la ciudad, la ciudadanía moderna se orienta a subrayar un ámbito individual de soberanía que los ciudadanos afirman frente a su propia comunidad y Estado. 
Pero veamos ahora cómo se produce este tránsito. De alguna manera, en occidente, estos ciudadanos definidos por su dimensión pública quedaron seducidos por el cristianismo y su división de lealtades: a Dios lo que es de Dios, y al César lo que es del César. Pero estas dos lealtades no estaban en equilibrio. Con San Agustín (354-430), el hombre cristiano trasladó su lealtad principal de la ciudad mundana a la celestial, a la ciudad de Dios. Las virtudes dejaron de servir directamente al sostenimiento de la ciudad terrenal, perdieron su dimensión colectiva, y adquirieron el sentido de preparación individual para la salvación como acceso a una comunidad más alta. Curiosamente, la virtud principal devino no la participación activa en la res publica sino la obediencia.

A su tiempo, nacieron otros poderes políticos, como el emperador y el papado, y finalmente los Estados, más fuertes y más eficaces que ciudades e imperios. De la desaparición del mundo de las ciudades y de la crisis de los poderes transnacionales del Papa y del emperador nacería el mundo de los Estados-nación. Y en este mundo, de forma gradual, nació la concepción liberal de la ciudadanía. Esta concepción está ligada no a la vida pública de los individuos, sino al aseguramiento de sus bienes privados. Thomas Hobbes en el Leviatán contrasta de forma bien expresiva los dos conceptos de libertad y de ciudadanía que están en liza. Así, señala que los habitantes de Luca habían tenido el capricho de rotular en las torres de la ciudad - los edificios republicanos en general gustan de convertirse en símbolos de la comunidad política - con la palabra libertad. Y señalaba que estos infelices se creían libres cuando quien era libre era su ciudad, mientras ellos carecían de toda libertad frente a ella. En lo que respecta a la libertad individual lo mismo daba Lucca que Constantinopla, símbolo entonces del despotismo oriental ${ }^{16}$.

La ciudadanía liberal, que empieza a avizorarse de forma incipiente en Hobbes, es una ciudadanía radicalmente distinta a la hasta ahora examinada, es la ciudadanía de la afirmación de los derechos individuales frente a la propia comunidad-ciudad. Es un tipo de ciudadanía en la que la dimensión pública se ve sustituida o seriamente restringida por una dimensión privada muy importante: uno tiene derechos, uno tiene una soberanía distinta, que no puede ser revocada por la propia ciudad; uno tiene leyes que le protegen frente a sus compatriotas. El tipo de hombre que se postula ya no es un ser virtuoso que antepone el bien público en sus decisiones y en sus actos, sino que es eminentemente privado, individualista. La dimensión pública queda eclipsada

${ }^{16}$ De hecho, Hobbes arremete de forma explícita contra la ciudadanía antigua como forma de libertad: «Los atenienses y los romanos eran libres, es decir, eran Estados libres; no es que cada hombre en particular tuviese la libertad de oponerse a quien lo representaba, sino que su representante tenía la libertad de resistir o de invadir a otros pueblos. En las torretas de la ciudad de Luca está inscrita, todavía hoy, en grandes caracteres, la palabra LIBERTAS; y, sin embargo, nadie podrá de ello inferir que un individuo particular tenga allí más libertad, o que esté más exento de cumplir su servicio para con el Estado, que en Constantinopla. Tanto si el Estado es monárquico, como si es popular, la libertad será siempre la misma», Leviatán, Madrid, Alianza, 1989 [1651], Segunda Parte, Capítulo 21, p. 177. 
por la afirmación de la privacidad del individuo poseedor. Y no sólo esto, la dimensión activa de la ciudadanía sucumbe, en este tránsito, y del ciudadano se pasa al súbdito, de la vida activa, al retiro privado. Carlos Thiebaut, un defensor contemporáneo de la ciudadanía de las ciudades dice que ser ciudadano «no es resultado de lo que tenemos (cómo tenemos asignado un sistema de libertades, cómo estamos insertos en las estructuras de la riqueza y de poder, cómo coordinamos nuestras acciones) cuanto de lo que hacemos: del ejercicio que es nuestra participación en aquello que hacemos, la ciudad» ${ }^{17}$. Y contrapone este ciudadano participante, que hace ciudad, al ciudadano de Hobbes que aparece en De Cive: «para Hobbes, contra lo que veníamos diciendo, el ciudadano pertenece como súbdito a una forma de poder. Su pertenencia está dada en el conjunto de sus obligaciones que, en forma de deberes, nacen de sus deseos y disposiciones naturales. El ciudadano pertenece a un orden político porque somete su voluntad natural a la voluntad política suprema» ${ }^{18}$.

Sin embargo, en la construcción de la ciudadanía liberal el momento hobbesiano es únicamente un episodio. La ciudadanía liberal no se reduce a la conversión de los ciudadanos en súbditos. La ciudadanía liberal se caracteriza, sobre todo, por la conversión del súbdito en ciudadano. Pero esto no quiere decir que los súbditos se convertirán en los ciudadanos participantes del elegante libro de Thiebaut, todo lo contrario, los ciudadanos permutarán sus obligaciones por derechos manteniendo un fin idéntico: la protección de sus bienes y de su vida privada.

La manera en que se construye el concepto liberal de ciudadanía es también, como en el concepto anterior, resultado de una relación entre los individuos y el Estado. Pero el resultado es sustancialmente distinto. También, como ocurría en el concepto anterior de ciudadanía, sus rasgos elementales nos resultan familiares. Así, cuando protestamos porque no nos gusta que la policía nos atropelle o que se inmiscuyan las instituciones del Estado en nuestra casa, o que se adueñen de nuestra correspondencia, o fisguen nuestra intimidad, y apelamos a unos derechos humanos, intrínsecos a nuestra persona, y que hacemos valer en nuestra defensa, estamos apelando expresamente a la ciudadanía liberal: un ámbito exclusivo de soberanía privada.

Hay muchas teorías acerca de cómo se construye esta ciudadanía, que tiene que ver con el declive, en parte, de las repúblicas - y digo las viejas repúblicasy el triunfo de una forma política bien distinta, mucho más eficiente en la centralización del poder político y, sobre todo, en términos militares: el Estado nación. El Estado nación, al igual que las viejas repúblicas, tiene necesidades que han de ser satisfechas por los ciudadanos: su sostenimiento impositivo y su defensa militar, pero también el cumplimiento de la ley o la obediencia política. Pero ahora ya no hay una identidad entre los ciudadanos y el Estado. Los ciudadanos preceden al Estado en sus derechos y prerrogativas, y construyen

\footnotetext{
${ }^{17}$ Carlos Thiebaut, Vindicación del ciudadano, Barcelona, Paidós, 1998, p. 25.

${ }^{18}$ Ibid., p. 26.
} 
un Estado para proteger aquello que ya poseían individualmente. Este mito, bien distinto del de la ciudadanía, es el del contrato social. Los mitos suelen tener algo de realidad y aquí el ingrediente de realidad es que el Estado ya no es la encarnación de una voluntad colectiva sino un instrumento subordinado a la soberanía de los individuos. En su forma más básica el Estado liberal está orientado a la protección de los derechos pre-políticos de los ciudadanos (vida, libertades y propiedad). Son ciudadanos porque se han asociado (la sociedad civil frente al estado de naturaleza) formando grupos, y se han asociado (son una sociedad no una comunidad) de forma benéfica, esto es, para beneficio mutuo de todos los integrantes: la ciudadanía significa protección de los derechos reconocidos por la sociedad.

Sin embargo, de forma harto paradójica, esta protección de los individuos a través del Estado exige, de forma casi estructural, una ampliación del concepto de ciudadanía. En el argumento liberal se parte, para justificar los derechos, del individuo privado con derechos pre-políticos, y ésta es la aportación de Thomas Hobbes. Pero la protección de estos derechos pre-políticos precisa, paradójicamente, de un ciudadano participante políticamente. Esto segundo se desarrolla en el Segundo Tratado sobre el Gobierno Civil de Locke. El ciudadano otorga un consentimiento limitado al poder político para que ejerza esta protección de derechos pero se reserva la posibilidad de controlar al poder político de forma permanente. Lo interesante es que ahora, a diferencia de lo que ocurría en el modelo republicano, la participación se orienta a la protección de los derechos individuales y no al ejercicio colectivo del autogobierno ${ }^{19}$.

Por tanto, la relación entre los individuos y sus autoridades políticas va cristalizando en una serie de derechos que otorgan seguridad jurídica sobre los bienes particulares, es decir, la ciudadanía equivale a derechos civiles. Estos derechos civiles, en aquellos lugares en los que el liberalismo triunfó originariamente - estamos hablando de un sitio excepcional, que es el Reino Unido-, dan paso enseguida a los derechos políticos. La existencia misma de derechos individuales significa una limitación de la soberanía del Estado y la protección de esta soberanía de los individuos frente al estado exigía mecanismos de responsabilidad política de forma que el estado estuviera de facto sometido al control de los ciudadanos. Los derechos políticos no son, en principio, una reinstauración del ideal del ciudadano total, sino el correlato natural de la protección de los derechos civiles. La Declaración de Independencia de los Estados Unidos es un buen ejemplo de cómo la protección de los derechos

\footnotetext{
${ }^{19}$ Esta dimensión individual de la libertad puede verse en estas palabras de Locke: «La libertad natural del hombre consiste en estar libre de cualquier poder superior sobre la tierra, y en no hallarse sometido a la voluntad o a la autoridad legislativa de hombre alguno, sino adoptar como norma, exclusivamente, la ley de la naturaleza. La libertad del hombre en sociedad es la de no estar bajo más poder legislativo que el que haya sido establecido por consentimiento en el seno del Estado», Segundo Tratado sobre el Gobierno Civil, Madrid, Alianza, 1990 [1690], capítulo cuarto, núm. 22, p. 52.
} 
civiles precisa de derechos políticos desde el punto de vista de los gobernados. Cuando los ciudadanos de las trece colonias americanas se niegan a pagar impuestos si no tienen representación política están señalando que hay un incumplimiento por parte del Estado en la protección de los derechos individuales que dieron lugar a la constitución de la comunidad política y que, al no haber cauces por los que exigir la restauración de los derechos afectados, se hace precisa la constitución de una nueva sociedad política, esto es, la independencia.

La relación entre los derechos civiles y los políticos es meridiana en el liberalismo. Sin embargo, el liberalismo sufrió una mutación radical tras la Segunda Guerra Mundial. Entonces apareció una tercera generación de derechos: los derechos sociales. Estos derechos, a diferencia de los anteriores, no son formales sino sustantivos. Son una especie de cuerpo extraño introducido en la lógica liberal de la ciudadanía y por ello muchos no los han aceptado. La idea de los derechos sociales fue introducida en el Reino Unido por aquellos liberales, como J. S. Mill, que pensaban que sin la satisfacción de las necesidades básicas de los individuos, las libertades y derechos liberales quedaban convertidos en humo. Esta idea de la necesidad de una justicia social sobre la que fundar el despliegue de la libertad individual se convirtió en política oficial del Reino Unido tras la Segunda Guerra Mundial. El informe Beveridge dio paso a la construcción, desde el liberalismo, de un Estado asistencial. Las consecuencias para la ciudadanía liberal fueron ambiguas: por una parte, aumentó de forma exponencial el bienestar y el desarrollo socio cultural de los individuos (aunque las consecuencias a largo plazo han sido menos positivas para la economía británica, para algunos estas consecuencias perversas se extendieron a la sociedad en su conjunto). Por otra parte, ésta ya sí inmediatamente negativa, la ciudadanía liberal quedó definida únicamente en términos de derechos (ilimitados) de individuos y grupos frente al Estado. Desapareció la contraparte de las obligaciones de los individuos hacia el Estado. Así se construyó un Estado hiper-responsable y desmesurado, una especie de padre protector de los ciudadanos, en todos los ámbitos de la vida social, que produjo que los ciudadanos devinieron radicalmente irresponsables o pasivos (se olvidaron de los costes de la libertad: de la participación política y del sostenimiento, en todos sus sentidos, de las instituciones que velan por el mantenimiento de su libertad). Se puso en marcha una lógica perversa por la que los individuos van demandando cada vez más al Estado y, al mismo tiempo, los partidos políticos prometen cada vez más al ciudadano para conseguir apoyo electoral. Esta combinación explosiva es la que ha sido retratada en numerosas obras sobre la crisis fiscal del Estado, los problemas de deslegitimación en el capitalismo tardío, la sobrecarga del gobierno o los problemas de gobernabilidad.

Bien lejos de esta percepción negativa, T. H. Marshall, en su famoso artículo, «Ciudadanía y clase social», señalaba cómo la ciudadanía liberal puede contemplarse como una secuencia que progresa a medida que la construcción 
de la libertad de los ciudadanos va integrando una mayor igualdad de los mismos. Así habrían aparecido en el siglo XVIII los derechos civiles; en el siglo XIX los derechos políticos; en el siglo xx los derechos sociales, culminación del progreso social y político. Las cosas, sin embargo, no están tan claras, aunque tampoco puede olvidarse que Marshall escribió su artículo en 1959, cuando el Estado de bienestar británico llegaba a su apogeo y cuando las patologías sociales de una ciudadanía liberal entendida únicamente como derechos frente al Estado aún apenas se habían manifestado.

De hecho, para algunos autores, como Richard Pipes o Pocock (en el artículo ya citado), la ciudadanía liberal se caracteriza por la capacidad de los ciudadanos para controlar el poder político. Pero aquí controlar no significa que los ciudadanos gobiernen de forma colectiva, sino que mantengan bajo control al poder político. Pocock hace una reivindicación polémica del individualismo posesivo como esencia de la ciudadanía liberal frente al mito de la ciudadanía (el ciudadano como sujeto público y activo reivindicado por los defensores, como Macpherson, de la democracia participativa). Pipes, por su parte, señala como el igualitarismo social del liberalismo moderno tiene consecuencias desastrosas para la libertad, es más, constituye la principal amenaza para la libertad. Los liberales clásicos, por el contrario, eran muy conscientes de que la libertad está firmemente ligada a la propiedad y que, si esta última se debilita por medio del igualitarismo democrático, la libertad desaparece.

Esto no quiere decir que en la lógica liberal el ciudadano tenga únicamente derechos frente al Estado. En este caso el derecho pre-político a la propiedad, sin que esto entrañe, a su vez, obligaciones hacia el Estado. Stephen Holmes y Cass R. Sunstein han mostrado cómo las obligaciones hacia el Estado, en contra de lo que creen los llamados libertarios, constituyen uno de los ingredientes esenciales de la ciudadanía liberal. El argumento no puede ser más diáfano: La defensa de los derechos de los ciudadanos es la primera obligación del Estado; la satisfacción de esta obligación precisa de instituciones y personal especializado y cuantioso; por tanto, la protección de los derechos tiene costes elevados que, necesariamente, tendrán que ser sufragados por los ciudadanos; si no se asumen los costes no tendremos Estado, pero tampoco tendremos derechos ${ }^{20}$.

Volviendo al tema de la propiedad, para Pipes el ciudadano ha de ser definido como individuo poseedor y esto le hace ser doblemente pesimista: respecto a la capacidad de las democracias para defender el derecho de propiedad (la clave de la ciudadanía moderna), tal como demuestra la historia

\footnotetext{
${ }^{20}$ Para Holmes y Sunstein, «la simple percepción de que los derechos tienen costes apunta inevitablemente a la valoración del estado y de las diversas cosas buenas que hace el Estado, muchas de ellas tan dadas por sentado que el observador poco atento ni se dará cuenta (...) Las decisiones políticas no han de tomarse sobre la base de una presunta hostilidad entre la libertad y hacienda, porque si de verdad estuvieran enfrentadas, todas nuestras libertades básicas estarían condenadas a la abolición», The Cost of Rights. Why Liberty Depends on Taxes, Nueva York, Norton, 1999, p. 31.
} 
de la posguerra en Occidente y, también, respecto a la hegemonía amenazante del igualitarismo social como pensamiento. Como señala de forma harto expresiva: «La tendencia parece indicar que en la modernidad los ciudadanos de las democracias están dispuestos irresponsablemente a renunciar a sus libertades a cambio de igualdad social (junto a seguridad económica), aparentemente ajenos a las consecuencias (...) El concepto mismo de Estado de bienestar, tal como ha evolucionado en la segunda mitad del siglo xx es incompatible con la libertad individual porque permite que diversos grupos con necesidades comunes se combinen y exijan el derecho a su satisfacción a expensas de la sociedad, en un proceso que hace crecer sin parar el poder del Estado que actúa a su favor» ${ }^{21}$.

Por tanto, la igualdad social, que Aristóteles señalaba como un requisito para la existencia de la democracia, puede ser una amenaza para el concepto liberal de ciudadanía. Hay, sin embargo, otro tipo de igualdad que sí es esencial para la ciudadanía liberal y, a su vez, este tipo de igualdad se ve hoy día amenazada. Por ejemplo, esto puede verse en la obra reciente del filósofo polaco Leszek Kolakowski. Éste combina la crítica mordaz de la igualdad social con la defensa de una igualdad liberal amenazada. De la primera dice lo siguiente en referencia al socialismo real: se trataba de una igualdad en la que no importaba que los pobres fueran más pobres, «lo básico era que nadie debía ser más rico que los demás». Y cuenta la siguiente anécdota: «Dios le dijo a un campesino ruso: "Te daré todo lo que quieras, pero aquello que pidas y recibas lo tendrá tu vecino en doble medida. ¿Qué te gustaría?". Y el campesino contestó: "Por favor, Dios, arráncame un ojo". Ése [dice Kolakowski] es el verdadero igualitarismo.» De la segunda igualdad, la liberal, dice, en tono no menos apasionado: «la igualdad en dignidad humana (...) y la igualdad de derechos y deberes que conlleva es un requisito esencial si no queremos retroceder a la barbarie» ${ }^{22}$.

$\mathrm{Y}$, sin embargo, este último concepto de igualdad está hoy seriamente cuestionado. La igualdad de derechos y deberes que implica la ciudadanía liberal se rechaza como una forma de opresión que favorece a los grupos dominantes o hegemónicos en la sociedad y se propone, como alternativa liberadora, una concepción diferenciada o multicultural de la ciudadanía. La percepción de asedio a la concepción liberal de la ciudadanía desde este ángulo es claramente visible en la última obra de Giovanni Sartori. Allí se denuncia que si hasta ahora se aceptaba que «el principio de ciudadanía produce ciudadanos iguales - iguales en sus derechos y deberes de ciudadanos- y que, viceversa, sin ciudadanos iguales no puede haber ciudadanía» ${ }^{23}$, hoy, por el contrario, se afirma que el bien a proteger es la diferencia de los ciudadanos

\footnotetext{
${ }^{21}$ Richard Pipes, Property and Freedom, Nueva York, Knopf, 1999, p. 284.

${ }^{22}$ Leszek Kolakowski, Libertad, fortuna, mentira y traición, Barcelona, Paidós, 2001, pp. 24 y 25 respectivamente.

${ }^{23}$ Giovanni Sartori, La sociedad multiétnica, Madrid, Taurus, 2001, p. 99.
} 
qua ciudadanos. Para Sartori esto significa una inversión o regresión en el desarrollo de la ciudadanía. La ciudadanía significa el paso del privilegio al derecho. $\mathrm{Y}$ «los derechos del ciudadano son tales porque son los mismos para todos» ${ }^{24}$. Si los derechos son distintos, entonces volveremos al privilegio. Para algunos, como Kymlicka, Taylor y otros, este paso hacia la ciudadanía diferenciada es un avance más en la lógica del despliegue de la ciudadanía señalada por Marshall. Tras los derechos sociales, los derechos culturales. Pero este movimiento es muy peligroso desde la perspectiva de la lógica liberal de la ciudadanía. Por una parte, acumula todos los riesgos que, para la ciudadanía liberal, entraña el igualitarismo social, pero añade, a éstos, la quiebra de la igualdad que sí es esencial para la ciudadanía liberal: la de los derechos y las obligaciones. La respuesta de Sartori, que no voy a valorar, no puede ser más contundente: «Como afirma concisamente Dahrendorf: "los derechos de ciudadanía son la esencia de la sociedad abierta". Lo que me induce a añadir que si se reformulan en "derechos de ciudadanías" (plurales y separadas), la sociedad abierta se rompe y subdivide en sociedades cerradas. Abolida la servidumbre de la gleba que ligaba al campesino con la tierra, hoy tenemos el peligro de inventar una "servidumbre de la etnia" ${ }^{25}$.

En suma, la ciudadanía de los Estados es muy distinta de la de las ciudades. Aquí la he asociado a la ciudadanía liberal, una ciudadanía en la que el ciudadano es el hombre privado, el individuo poseedor. Este hombre privado busca proteger lo suyo en el terreno de la política a través de un mínimo de participación política: la participación política convencional o el ejercicio de los derechos políticos. La ciudadanía de los Estados o liberal está caracterizada por tener la forma de un contrato: derechos y obligaciones. Ninguno de los extremos del contrato puede desatenderse porque la libertad de los individuos peligra. Si la ciudadanía deviene igualdad social, el estado se fortalece y la libertad de los individuos flaquea. Si la ciudadanía, como en Hobbes, queda reducida a obligaciones, el ciudadano se convierte en súbdito. Si se pierde de vista que hay un límite al reconocimiento de los derechos y éste se traspasa alterando la igualdad de derechos y obligaciones para todos, la ciudadanía liberal nuevamente peligra. Además, como hemos visto, la protección de los derechos (civiles y políticos) asociados a la ciudadanía liberal precisa del cumplimiento, por parte de los ciudadanos, de sus obligaciones (especialmente de las impositivas) y si éstas no se satisfacen, desaparece el Estado, pero, también, los derechos liberales (aquí es importante recordar que no hay derechos sin instituciones que los respalden, algo que con frecuencia olvida el internacionalismo occidental).

Por último, el espacio de este tipo de ciudadanía es el Estado. El Estado es una sociedad artificial destinada a la protección de los derechos de los individuos mediante la cooperación de los mismos. Sin embargo, el Estado,

\footnotetext{
${ }^{24}$ Ibid., p. 103.

${ }^{25}$ Ibid., p. 105.
} 
debido a la globalización, cada vez tiene más difícil atender a los compromisos contraídos con sus ciudadanos. El Estado, de alguna manera, ya no es capaz de ejercer la soberanía externa y, por lo tanto, tampoco puede velar permanentemente por la protección interna de los derechos de los ciudadanos. Esta crisis del Estado, del orden de Westfalia, nos lleva al tercer espacio de la ciudadanía: la civitas maxima o cosmópolis.

\section{Los ciudadanos del mundo}

Hannah Arendt, al interrogarse acerca de si Karl Jaspers era un ciudadano del mundo dejó dicho que «nadie puede ser ciudadano del mundo como lo es de su país (...) Un ciudadano es por definición un ciudadano entre ciudadanos de un país entre países. Sus derechos y obligaciones están definidos y limitados, no sólo por sus co-ciudadanos, sino también por los límites del territorio. La filosofía puede imaginar la tierra como el hogar de la humanidad y de una ley no escrita, eterna y válida para todos. La política se ocupa de los hombres, de los nacionales de muchos países que son herederos de muchos pasados; sus leyes son barreras positivamente establecidas que acotan, protegen y limitan el espacio en el que la libertad no es un concepto sino una realidad viva, política» ${ }^{26}$. Por tanto, la expresión ciudadanos del mundo es distinta de la de ciudadanos de las ciudades y ciudadanos de los Estados, tiene a lo sumo, un sentido de identificación moral, afectiva, con la humanidad, pero carece de toda dimensión política.

Ser ciudadano del mundo carece de las dimensiones propias de la ciudadanía de las ciudades: no hay participación política en la ciudadanía del mundo, tampoco hay posición ni privilegio (porque de hecho la humanidad es una categoría máximamente inclusiva). De hecho, si el eclipse de la ciudadanía republicana del autogobierno viene dado por el desarrollo de un tipo de asociación política, el Estado nación, impersonal y en el que la actividad política del ciudadano participante se hace imposible, iqué no ocurrirá con la participación política cuando la ciudad es toda la Tierra? Al mismo tiempo, ciudadanía es privilegio y, por tanto, exclusión. ¿Qué sentido tiene una ciudadanía de la que nadie está excluido?

$\mathrm{Si}$ atendemos al segundo espacio de la ciudadanía y lo contrastamos con la expresión ciudadanos del mundo, las conclusiones que obtendremos no son muy distintas de las anteriores. En el modelo de la ciudadanía liberal ésta se entiende como el reconocimiento de derechos que permiten el desarrollo sin interferencias de la soberanía de los individuos. El Estado se concibe, en relación con esta ciudadanía, como garante de los derechos propios de un tipo de asociación política particular entre individuos. ¿Puede hablarse de una ciudadanía cosmopolita a falta de instituciones que velen por la protección

${ }^{26}$ Hannah Arendt, Hombres en tiempos de oscuridad, Barcelona, Gedisa, 1990, p. 67. 
de un catálogo determinado de derechos, fruto de un contrato entre los individuos y el Estado, y asociados a unas obligaciones determinadas que han de satisfacer los individuos respecto a dicho Estado? De nuevo, lo dudo.

Sin embargo, la misma Hannah Arendt señala un dato crucial: «es verdad, por primera vez en la historia, que todos los pueblos de la tierra viven en un presente común» ${ }^{27}$. Esto significa que, a pesar de todo, la ciudadanía cosmopolita no es una expresión completamente abstracta, carente de sustancia política: de alguna manera somos parte de una misma comunidad, de una comunidad real y no sólo imaginada, que abarca a toda la humanidad. Javier Muguerza ha utilizado la metáfora de la Aeronave Espacial Tierra para describir esta paradoja: no hay duda de que estamos todos a bordo pero lo que no está claro es si «sería capaz de navegar sin zozobrar ni estrellarse (...) ni si $\tan$ siquiera sería capaz de despegar y levantar el vuelo» ${ }^{28}$. La comunidad cosmopolita a la que apunta la frase de Arendt y la reflexión de Muguerza es, por tanto, algo mucho más modesto que una comunidad política. La idea de una comunidad cosmopolita apunta a la búsqueda de acuerdos transnacionales que permitan abordar aquellos problemas que tiene la humanidad (una humanidad por primera vez real y no adivinada) y que rebasan el alcance de aquello que pueden hacer los Estados. Muguerza lo explica con toda claridad: se trataría de construir una comunidad cosmopolita «a la que, sin embargo, no me atrevería a llamar hoy por hoy "cosmopolítica", pues de momento no está claro que el cósmos sea una pólis ni quepa hablar, en consecuencia, de una ciudadanía cosmopolita, salvo con ese dispendio de retórica que lleva a algunos entusiastas a proclamarse "ciudadanos del mundo", cuando lo cierto es que al presente dicho mundo, sea para bien o para mal, más merecería el nombre de caópolis» ${ }^{29}$.

El concepto de ciudadanía cosmopolita apunta en primer lugar, por tanto, al establecimiento de un orden internacional más justo. Un orden internacional que se inspire en el funcionamiento de las democracias liberales, pero, y esto es importante, sin implicar la construcción de un terrorífico Leviatán global: «la idea misma de una única fuerza soberana gobernando toda la tierra, con el monopolio de todas las formas de violencia, incontrolada y no limitada por otros poderes soberanos es una pesadilla imperdonable y significaría el fin de toda vida política» ${ }^{30}$. Nadie parece, pues, dispuesto a defender la ciudadanía cosmopolita asociada a una improbable e indeseable Cosmópolis. De

${ }^{27}$ Ibid., p. 83 .

${ }^{28}$ Javier Muguerza, El puesto del hombre en la cosmópolis, Madrid, UNED, 1998, p. 15.

${ }^{29}$ Ibid., p. 10. Un proyecto sensato, realista, de comunidad política en el sentido kantiano y de Muguerza puede verse en John Rawls, El derecho de gentes, Barcelona, Paidós, 2001. Rawls presenta su proyecto como una utopía realista que «busca enseñarnos que es posible una democracia constitucional razonablemente justa como miembro de una sociedad de los pueblos razonablemente justa», p. 150.

${ }^{30}$ Hannah Arendt, op. cit., p. 81. 
hecho, Danilo Zolo, enemigo acérrimo de este presunto proyecto, reconoce al final de su libro Cosmópolis. Perspectiva y riesgos de un gobierno mundial ${ }^{31}$ que quizás «me he enzarzado en una quijotesca batalla contra molinos de viento cosmopolitas». Por tanto, los ciudadanos del mundo, si es que existen, lo son, en sentido político, en tanto ciudadanos de Estados realmente existentes.

En segundo lugar, el concepto, ciudadanos del mundo, más allá de la acepción anterior, refleja la preocupación moral por otros humanos que no pertenecen a nuestra comunidad política. Este concepto de ciudadano del mundo es el que ha querido recuperar Martha C. Nussbaum recientemente: «Los estoicos, seguidores de Diógenes, desarrollaron su imagen del kosmou politês (ciudadano del mundo), aduciendo que cada uno de nosotros habita en dos comunidades: la comunidad local en la que nacemos, y la comunidad de deliberación y aspiraciones humanas que "es verdaderamente grande y verdaderamente común, en la que no miramos esta esquina ni aquélla, sino que medimos las fronteras de nuestra nación por el sol" (Séneca, De otio). Ésta es la comunidad de la que, básicamente, emanan nuestras obligaciones morales» ${ }^{32}$. Cuando Arendt o Muguerza hablan de ciudadanos se refieren a la primera comunidad, la local, cuando hablan de un presente común o de la Aeronave Espacial Tierra, hacen referencia a que el resto de los humanos se han convertido en sujetos de nuestra preocupación moral.

Hasta el momento he señalado dos verdaderos espacios de la ciudadanía: la ciudadanía de las ciudades y la ciudadanía de los estados. La primera es la ciudadanía republicana, la segunda es la ciudadanía liberal. El presente de la ciudadanía es más complejo. Si de la primera ciudadanía nos quedan reflejos de sus rasgos de participación política y de exclusivismo, de la segunda nos resta la noción de libertad negativa asociada a unos derechos con tendencia a dispararse. La ciudadanía cosmopolita la hemos desestimado en tanto que, sustantivamente, se trataría un proyecto de reorganización de las relaciones internacionales o un ideal moral. Sin embargo, he presentado la globalización como un dato que afecta profundamente las bases de la ciudadanía liberal y que, por tanto, exige una respuesta cosmopolita (y no cosmopolítica) a dicho desafío. Como modelo de una respuesta cosmopolita a la crisis de la ciudadanía liberal presentaré, a continuación, el modelo de ciudadanía que puede asociarse al proyecto de Tony Blair conocido como Tercera Vía.

Para Blair, la ciudadanía liberal, defendida por el radicalismo inglés hasta finales del siglo pasado, se contaminó con algo llamado socialismo. Socialismo, en Blair, es sinónimo de intervención masiva del Estado en la sociedad, de ineficiencia, de paternalismo y, finalmente de declive y decadencia social y económica. Por tanto, el dato básico sobre el que se construye la tercera vía de Blair es el de la muerte del socialismo. Esto es, la ciudadanía social de

${ }^{31}$ Danilo Zolo, Cosmópolis. Perspectiva y riesgos de un gobierno mundial, Barcelona, Paidós, 2000, p. 243.

${ }^{32}$ Martha C. Nussbaum, Los límites del patriotismo, Barcelona, Paidós, 1999, p. 17. 
Marshall ya no es ejemplo de una utopía promisoria de extensión social de la ciudadanía liberal sino más bien señal de disutópico control de la sociedad por el Estado (con la consiguiente restricción de libertad personal y, encima, de ineficacia en la creación de prosperidad). Por tanto, la tercera vía no sólo es una reestructuración de la socialdemocracia, es sobre todo un intento de dar respuestas nuevas ante problemas nuevos: los problemas del mundo globalizado, del mundo que vive ya las consecuencias de la modernidad (como diría A. Giddens).

En este contexto, lo que le preocupa a Tony Blair es de qué manera puede rescatarse el ideal de la justicia social, el ingrediente perenne de la tradición socialdemócrata, que él distingue muy radicalmente de la socialista —esta última es la tradición de las nacionalizaciones y la creación de economías dirigidas, aquélla es el intento desde el liberalismo de resolver los problemas de justicia social- en las circunstancias del mundo globalizado. Estos problemas ya no se podían resolver a través de la intervención en la economía, sino que tendría que hacerse de otra manera. ¿Y qué es lo que significa esto? Un cambio radical de la concepción de ciudadanía que había sido hegemónica en el Reino Unido desde la Segunda Guerra Mundial: el abandono del concepto de la ciudadanía social, del individuo que podía esperar la asistencia del Estado en todas las dimensiones de su vida.

En el Reino Unido, esta ciudadanía social, la de los derechos sociales, se conoce como el consenso de posguerra, un consenso que ejemplificaba la convergencia de todos los partidos políticos en un acuerdo básico acerca de las obligaciones sociales del Estado. En ese consenso participaban los conservadores, los liberales y, por supuesto, con entusiasmo, el Partido Laborista. La globalización en el Reino Unido ha producido, entre otras muchas cosas, el hundimiento de este modelo de ciudadanía y ha desencadenado la necesidad de su sustitución por uno nuevo. Por supuesto, esto no sólo es consecuencia de la globalización, sino también de factores endógenos que tienen que ver con el tipo peculiar de relaciones laborales propio de la industria británica de posguerra.

Tony Blair y sus asesores son acusados de una manera muy dura de neoliberales, de ex-socialistas que han hecho de la necesidad virtud y que han abandonado sus principios por una ideología a la moda de los nuevos poderes transnacionales. Sin embargo, yo creo que merecen que se les tome en cuenta porque han tenido la valentía de afrontar el problema. Si nosotros atendemos a lo que hacen otros políticos de partidos socialistas o socialdemócratas europeos, que mantienen en su discurso la ideología del Estado asistencial, descubriremos que las diferencias con la tercera vía son sobre todo de tipo retórico y que en sus políticas públicas y en política económica hacen sencillamente lo que pueden. Esto es, se amoldan a la hegemonía de la globalización económica pero, a diferencia de la tercera vía, lo hacen de forma vergonzante, sin tomar la iniciativa a la hora de organizar políticas públicas que salvaguarden la justicia 
social, en un horizonte en el que el mercado se ha vuelto el árbitro en el terreno de la economía. Tony Blair ejemplifica, por tanto, un cambio de paradigma en cuanto a la concepción de la ciudadanía. Hay una vuelta desde la ciudadanía social (socialista) a una concepción básicamente liberal de la misma: derechos civiles y políticos. Y esto se hace a través de una enfática recuperación del concepto de responsabilidad individual.

En suma, el ciudadano cosmopolita no es un ciudadano en sentido político. En todo caso, el ciudadano de los Estados es, en sentido subsidiario, un ciudadano cosmopolita. Aquí el cosmopolitismo significaría el traslado, de alguna manera, de las instituciones políticas a la arena internacional. En un segundo sentido, ciudadano cosmopolita es una manera de describir el tipo de obligaciones morales que tenemos para aquellos que viven en nuestro propio presente. Por último, en tercer lugar, la globalización exige una respuesta cosmopolita de la ciudadanía liberal o de los Estados. En este sentido, la tercera vía puede verse como una respuesta a las patologías de la ciudadanía liberal y a los desafíos de la globalización. No hay propiamente una ciudadanía cosmopolita porque no hay un contrato entre los individuos y un geogobierno mundial. Ni siquiera las instituciones transnacionales merecen ese crédito. Como dice Bernard Crick: «sigue siendo difícil encontrar en las relaciones internacionales equivalentes reales a los procesos y las instituciones de la política libre en los países libres. Los que existen parecen poco adecuados y merecen escasa defensa y pocas alabanzas» ${ }^{33}$.

No hay ciudadanos cosmopolitas salvo en sentido moral y no hay ciudadanía cosmopolita salvo en sentido figurado. La metafísica de los derechos que asigna los mismos de forma genérica a la humanidad es aquí, si cabe, más dolorosa que en ningún otro espacio. Hay que repetir que no hay derechos sin instituciones que los salvaguarden y, hoy por hoy, esas instituciones corresponden a los Estados. Por último, la civitas maxima, la Aeronave Espacial Tierra, es más un vehículo errático al que hemos sido arrojados de forma caótica que ese lugar, el más excelente de toda la compañía humana, al que Castrillo denominaba ciudad.

\section{Conclusión}

En suma, y a modo de conclusión, derechos y ciudadanía son ingredientes básicos de la concepción liberal de la política. La ciudadanía antigua o republicana significaba a un tiempo privilegio y participación política. La ciudadanía liberal retiene en parte ambos ingredientes pero otorgándoles un sesgo radicalmente distinto. La ciudadanía es un contrato entre los individuos y el Estado en el que quedan reflejados las obligaciones y derechos de uno y otro. La ciudadanía antigua o republicana enfatiza, como en Rousseau, la dimensión

\footnotetext{
${ }^{33}$ Bernard Crick, En defensa de la política, Barcelona, Tusquets, 2001, p. 320.
} 
pública de la ciudadanía: el ciudadano como miembro de un sujeto colectivo, la nación, que se expresa a través de la voluntad general. La ciudadanía liberal, por el contrario, significa en primer lugar, derechos frente a la propia comunidad: un ámbito de soberanía privada. Pero esto no quiere decir que carezca de dimensión pública. La sociedad es entendida como una empresa benéfica, esto es, como un instrumento de beneficio mutuo a través de la cooperación. Por tanto, la dimensión de las obligaciones no puede desligarse del reconocimiento de derechos.

Sin embargo, históricamente, la ciudadanía liberal ha tendido a enfatizar (debido probablemente a la estructura del sistema político de las democracias liberales contemporáneas) la dimensión de los derechos, al tiempo que las obligaciones quedan oscurecidas o silenciadas. La ciudadanía otorga privilegios (derechos) pero éstos no son inherentes a la naturaleza humana, sino el resultado de procesos concretos y precisos de negociación de derechos y obligaciones. Este olvido, que los derechos son el resultado de una negociación política (contingente, histórica y concreta), ha permitido un crecimiento exponencial de los derechos en la ciudadanía liberal a costa de las obligaciones. La tercera vía de Blair, a pesar de lo coyuntural de su nacimiento (la crisis del viejo laborismo británico) significa una recuperación de la ciudadanía liberal doblemente interesante: por un lado, entraña la recuperación de la dimensión responsabilidad de los individuos en tanto ciudadanos (que había desaparecido con la extensión del desarrollo del Estado de bienestar y de la ciudadanía social y económica). Y, por otro, supone una respuesta a los retos que plantea la globalización a la ciudadanía liberal. El Estado, bajo esta concepción, vuelve a su papel de protector de los derechos individuales, un árbitro entre los individuos y la sociedad, pero deja de ser el encargado de la provisión de todos aquellos bienes que demanda la sociedad. Supone, además, una recuperación interesante porque aborda el problema de la justicia social en la era de la globalización. Y responde a este desafío, básicamente, a través de la reforma de la educación: de la capacitación de los individuos para que puedan desarrollarse en un mundo crecientemente incierto y cambiante.

La ciudadanía, por último, no puede entenderse sin hacer referencia a cada uno de los espacios que he mencionado. Si se quiere que el concepto de ciudadanía siendo útil para describir y orientar la acción política de los individuos, habrá de referirse en cada caso concreto a estas tres dimensiones. En primer lugar, la ciudadanía, más allá del mito, implica participación política; además, la ciudadanía equivale a igualdad de derechos y obligaciones, y en tercer lugar, la ciudadanía no es ajena a los problemas globales. Estos tres espacios de la ciudadanía hacen que los ciudadanos reales estén sometidos a tensiones, a lealtades en ocasiones opuestas y a contradicciones. Pero me parece que si no se consignan estos tres espacios de la ciudadanía, el concepto mismo se vacía de significado y su uso se vuelve mera retórica que sobrevuela la realidad sin aprehenderla, describirla o interpretarla. 


\section{BIBLIOGRAFÍA}

Arendt, Hannah (1990): Hombres en tiempos de oscuridad, Barcelona, Gedisa.

BeIner, Ronald (1995): Theorizing Citizenship, Albany, SUNY.

Castrillo Alonso (1958 [1521]): Tractado de Republica, Madrid, Instituto de Estudios Políticos.

CRICK, Bernard (2001): En defensa de la política, Barcelona, Tusquets.

Hansen, Mogens Herman (1999): The Athenian Democracy in the Age of Demosthenes, Norman, University of Oklahoma Press.

Held, D., et al. (1999): Global Transformations, Cambridge, Polity.

Heller, Agnes, y Fehér, Ferenc (1989): Políticas de la postmodernidad, Barcelona, Península.

HobBes, Thomas (2000 [1642]): De Cive, Madrid, Alianza.

- (1998 [1651]): Leviatán, Madrid, Alianza.

Holmes, Stephen, y Sunstein, Cass R. (1999): The Cost of Rights, Nueva York, Norton. KolaKowsKi, Leszek (2001): Libertad, fortuna, mentira y traición, Barcelona, Paidós. Locke, John (1990 [1690]): Segundo Tratado sobre el Gobierno Civil, Madrid, Alianza. Marshall, T. H., y Bottomore, Tom (1992 [1950]): Citizenship and Social Class, Londres, Pluto Press.

Muguerza, Javier (1998): El puesto del hombre en la cosmópolis, Madrid, UNED. Nussbaum, Martha C. (1999): Los límites del patriotismo, Barcelona, Paidós.

PiPPES, Richard (1999): Property and Freedom, Nueva York, Knopf.

RAwls, John (2001): El derecho de gentes, Barcelona, Paidós.

Rivero, Ángel (2001): «Ciudadanía y globalización», Anthropos, núm. 191.

- (2000): «Ciudadanos, Repúblicas, Estados y Cosmópolis: algunos temas de la teoría política contemporánea», Revista Española de Ciencia Política, núm. 3, octubre.

SARTORI, Giovanni (2001): La sociedad multiétnica, Barcelona, Taurus.

Sinclair, R. K. (1999): Democracia y participación en Atenas, Madrid, Alianza.

SKInNER, Quentin (1998): Liberty before Liberalism, Cambridge, Cambridge University Press.

Thiebaut, Carlos (1998): Vindicación del ciudadano, Barcelona, Paidós.

Valdeavellano, Luis G. de (1998): Curso de historia de las instituciones españolas, Madrid, Alianza.

Viroli, Maurizio (1997): Por amor a la patria, Madrid, Acento Editorial.

- (2001): «El significado de la libertad», Revista de Libros, núm. 52, abril.

Zolo, Danilo (2000): Cosmópolis: perspectiva y riesgos de un gobierno mundial, Barcelona, Paidós. 